\begin{tabular}{|l|l|}
\hline DOI 10.31558/2307-2318.2020.4.8 & \\
УДК $331.103: 331.44: 364.08$ & JEL: J20, J24, J40, К31, O15 \\
\hline
\end{tabular}

Панченко I.B.,

кандидат економічних наук, доцент, Донецький національний університет імені Василя Стуса

ORCID: 0000-0001-5010-5810

i.panchenko@donnu.edu.ua

Середа Г.В.,

кандидат економічних наук, доцент, Донецький національний університет імені Василя Стуса

ORCID: 0000-0001-9222-1887

g.sereda@donnu.edu.ua

\title{
ТРАНСФОРМАЦІЯ СТРАТЕГІЧНИХ ІМПЕРАТИВІВ УПРАВЛІННЯ ПЕРСОНАЛОМ В УМОВАХ ПАНДЕМІЇ СОVID-19
}

У статті досліджено особливості трансформачії стратегічних імперативів управління персоналом в компаніях в умовах пандемії. Закцентовано увагу на тому, шо пандемія та пов'язана з нею економічна криза вимагають від власників компаній використання дієвих інструментів подолання негативних наслідків та пристосування до теперішніх умов існування на ринку, а також збереження головного ресурсу компанїперсоналу. Доведено, щчо у сучасних реаліях значною перевагою для компаній у конкурентній боротьбі за виживання можуть стати правильно встановлені стратегічні імперативи управління персоналом, щзо враховують зміни у внутрішньому та зовнішньому середовищі організащії, на ринку пращчі, в економіщі та суспільстві в цілому. Встановлено, щуо ключовими напрямами, на які керівництву компанії доцільно звертати увагу при формуванні HR-стратегіï, є: створення відчуття приналежності персоналу організації; забезпечення ефективної взаємодії людей і технологій; поширення системи накопичення знань та використання штучного інтелекту; забезпечення сприятливих умов для вирішення етичних проблем; створення комфортного середовища задля добробуту прачівників; сприяння зменшенню розбіжностей між різними поколіннями прачівників; формування системи розвитку персоналу та пристосування до змін; імплементація стратегії винагороди з фокусом на людину. Отримані результати пропонується використовувати для подальшого детального та системного вивчення впливу пандемії на трансформацію стратегічних імперативів управління персоналом в контексті глобальних змін трудових відносин.

Ключові слова: управління персоналом, стратегічні імперативи, трансформація, пандемія, персонал організачіï, HR-стратегія, організація праці.

Лim. -5

Постановка проблеми. В умовах всесвітньої пандемії COVID-19 та одночасної економічної кризи перед менеджментом компаній постають два ключових питання: мінімізація витрат та збереження людського потенціалу. Якщо перше питання входить до сфери інтересів загального менеджменту компанії, то друге питання зазвичай 
вирішується в межах кадрової стратегії, однак зараз спостерігається ситуація, коли часовий лаг планування зменшується до критичних величин, фактично відбувається динамічна трансформація стратегічного управління персоналом, фокусування на тактичних та оперативних проблемах компанії. В таких умовах прогностична функція стратегічного управління персоналом на період кризи відходить на другий план, a HRменеджери вимушені реагувати на виклики зовнішнього середовища та ринку праці майже миттєво, приймаючи антикризові рішення щодо ефективного використання та збереження персоналу.

Аналіз останніх досліджень і публікацій. Дослідження стратегічних аспектів управління персоналом знаходить своє відображення в багатьох наукових працях українських та закордонних вчених, зокрема М. Армстронга, I. Петрової, І. Ансоффа, А. Чандлера, К. Ендрюса, Г. Десслера, Г. Дмитренко, А. Єгоршина, Дж. Іванцевича, А. Кібанова, А. Лобанова, В. Маслова, Ю. Одегова, С. Шекшні та ін. Водночас, сучасні реалії та виклики суттєво впливають на процес формування HR-стратегій і вимагають від науковців та практиків пошуку найбільш ефективних науково-методологічних підходів до управління персоналом, що зумовлює актуальність обраного напряму дослідження.

Метою статті $\epsilon$ дослідження особливостей трансформації стратегічних імперативів управління персоналом під впливом змін, що відбуваються на ринку праці та у внутрішньоорганізаційному середовищі в умовах пандемії та економічної кризи.

Виклад основного матеріалу. Пандемія та пов'язана 3 нею економічна криза вимагають від власників компаній використання дієвих інструментів подолання негативних наслідків та пристосування до теперішніх умов існування на ринку, а також збереження головного ресурсу компанії - персоналу. В таких обставинах виграшну позицію займають компанії 3 розвиненою та гнучкою стратегією управління персоналом. Останнім часом, в бізнес-середовищі превалює думка про те, що в Україні взагалі неможливо прогнозувати свою діяльність на довгострокові періоди, враховуючи нестабільність економічної та політичної сфер країни. В цілому складно оцінити частку українських компаній, що мають у своєму розпорядженні дієві альтернативні стратегії управління персоналом на випадок кризи, проте, гіпотетично, ті з них, які все ж таки використовують цей інструмент, мають більш реальні шанси мінімізувати наслідки теперішніх соціально-економічних колапсів, пов'язаних з пандемією COVID-19. Отже, в сучасних реаліях значною перевагою для компаній у конкурентній боротьбі за виживання можуть стати правильно встановлені стратегічні імперативи управління персоналом, що враховують зміни у внутрішньому та зовнішньому середовищі організації, на ринку праці, в економіці та суспільстві в цілому. У контексті зазначеного слід виділити основні чинники та тренди, що на наш погляд, значною мірою впливають на формування сучасних HR-стратегій.

По-перше, слід відзначити суттєві зміни на ринку праці, що зумовлені пандемією COVID-19. За даними МОП пандемія коронавірусу може спричинити гірші наслідки для світового ринку праці, ніж фінансова криза 2008-2009 років. Прогнозується, що коронакриза призведе до скорочення 25 мільйонів робочих місць у світі. Водночас як у період фінансової кризи 2008-2009 років безробітних у світі побільшало на 22 мільйони осіб [1]. Український ринок праці теж відчув на собі ці негативні наслідки. 3 початку карантину в Україні статус безробітного отримали майже 432 тисячі осіб (станом на кінець серпня 2020 року), що на 67\% більше, ніж за аналогічний період 2019 року. Безробітними стали сотні тисяч громадян: як представники інтелектуальної праці, так і найпростіших професій [1]. Окрім очікуваних наслідків у вигляді безробіття і 
зменшення доходів населення, аналіз свідчить про три ключові тенденції, що притаманні сучасному «коронокризовому» ринку праці:

1. Максимальна оптимізація витрат. Як правило, в нинішній ситуації компанії намагаються максимально скоротити штат, залишаючи тільки співробітників, які здатні генерувати прибуток. Наслідком цієї тенденції $\epsilon$ перегляд системи мотивації співробітників у бік зниження фіксованої частини оплати і збільшення змінної, яка залежить від виконання планів.

2. Різке збільшення конкуренції на ринку праці. За даними кадрового порталу grc.ua, наприкінці 2020 року на одну вакансію стало припадати в 2-3 рази більше резюме, ніж це було в кінці 2019 року або на початку 2020 [1]. Іншою причиною конкуренції на ринку праці слід також вважати зменшення матеріальної мотивації працівників, що призводить до вимушеного пошуку ними більш високооплачуваної роботи.

3. Швидка зміна пріоритетів роботодавців. В умовах пандемії на ринку праці України різко змінились пріоритети роботодавців щодо пошуку необхідних спеціалістів. Така ситуація є досить очікуваною, що пов'язано з переходом великої кількості компаній на дистанційну роботу. У зв'язку з цим змінюються стратегії пошуку, підбору та розвитку персоналу в самих компаніях.

Окрім змін на ринку праці, слід також зазначити тенденцію до перегляду принципів організації трудової діяльності самих компаній в умовах пандемії, зокрема, перехід до підходу Flexible Working. Це сучасний гнучкий підхід до організації трудової діяльності, запроваджений в умовах короновірусної пандемії. Як правило Flexible Working передбачає об'єднання наборів до підходів організації праці, що включають в себе спільний набір простору, відсутність закріпленого робочого місця, мобільну та дистанційну роботу, гнучкий графік, неповний трудовий день, розподілення одних завдань між різними співробітниками й домашній офіс.

До основних переваг даної форми організації трудової діяльності відносяться:

залучення до компанії нового покоління працівників - мілленіалів;

забезпечення конкурентоспроможності на ринку праці із глобальними брендами за допомогою можливості гнучкого графіку;

можливість працювати 24/7, тобто потреба роботодавців від співробітників здійснювати професійні обов'язки поза стандартним робочим днем;

підвищення продуктивності праці, тобто співробітники із гнучким графіком виконують більшу кількість роботи, ніж очікує керівництво, за однакову оплату праці;

утримання персоналу за рахунок переваг віддаленої роботи;

ефективне використання робочого простору, що у свою чергу, знижує витрати компанії на обслуговування офісного майданчика.

У той же час, перехід на дистанційну форму роботи може мати і негативні прояви, серед яких слід відзначити наступні:

зменшення живого спілкування між працівниками;

можливе підвищення напруженості праці співробітників через більшу кількість завдань при роботі в дистанційному режимі;

посилення контролю з боку керівництва;

можливі витрати на придбання компанією програмного забезпечення для організації трудового процесу.

Зміна підходів до організації трудового процесу в умовах пандемії та перехід на гнучкі форми зайнятості працівників суттєво впливають на менеджмент компанії в цілому та роль самого менеджера. Відповідно змінюються і стратегічні імперативи 
управління персоналом, що базуються на новостворених умовах та можливостях. Зважаючи на це, керівництву компанії при формуванні своєї HR-стратегії, на наш погляд, слід звернути увагу на наступні аспекти:

1. Формування відчуття приналежності персоналу організації. Відчуття приналежності $є$ головним чинником залученості й фундаментальною потребою людини. Коли відчуття приналежності втрачається, працівники стають менш продуктивними, більше думають про звільнення й не рекомендуватимуть свою компанію як хорошого роботодавця. На здатність організації формувати відчуття приналежності найбільше впливають організаційна культура, поведінка лідерів та особисті взаємозв'язки.

2. Взаємодія людей і технологій. Пандемія COVID-19 показала, що технології не замінюють людину, а, навпаки, доповнюють і розширюють іiі можливості. Поточна криза дала можливість зрозуміти, що люди й технології є набагато потужнішими разом, ніж окремо. У цьому контексті компаніям слід зосередити свої зусилля на пошуку нових способів взаємодії людини і технологій. Компанії мають переглянути своє ставлення до технологій i, замість того, щоб розглядати їх як заміну людині, мають розробляти стратегії для доповнення чи поєднання можливостей технологій і людини. Це допоможе не лише оптимізувати витрати, а й створити цінність та врешті-решт додати значущості роботі своїх працівників.

3. Накопичення знань та штучний інтелект. В умовах пандемії доцільним $\epsilon$ використання потенціалу штучного інтелекту для побудови культури обміну та накопичення знань, що є не тільки практично корисним, а й зміцнює взаємодію між працівниками та забезпечує стійкість організації, даючи їй змогу протистояти й навіть процвітати в середовищі невизначеності та змін. За дослідженнями компанії Oracle виявило, що 64\% працівників довіряють роботу більше, ніж своєму керівнику. Половина звертається за порадою до робота, а не до менеджера. Завдяки штучному інтелекту адміністративні завдання можуть бути повністю автоматизовані, що дозволить менеджерам працювати над важливішими ініціативами [2].

4. Посилення уваги до етичних проблем. На сьогодні етичні проблеми стали актуальними майже в усіх сегментах персоналу, але найбільшого впливу зазнали фахівці, які працюють 3 альтернативними формами зайнятості. Деякі з них стикнулися з падінням попиту на їхні послуги та пов'язаними з цим фінансовими проблемами, інші - зі зростанням попиту та пов'язаним з цим підвищеним загрози здоров'ю. У квітні 2020 року Deloitte було проведене опитування, яке показало, що 70\% фрилансерів не задоволені підтримкою, яку вони отримували від своїх роботодавців під час пандемії [3].

5. Формування комфортного середовища задля добробуту працівників. Пандемія COVID-19 створила нагальну потребу в забезпеченні добробуту, а також фізичної, психічної й фінансової безпеки працівників. Через пандемію та віддалений режим роботи тривалість робочого дня збільшилась, що призвело до виснаження й емоційного вигорання працівників. Водночас серед персоналу збільшився рівень стресу через необхідність балансу між професійними та особистими потребами. За дослідженнями Deloitte менеджери витрачають 40-87\% свого часу на комунікацію 3 клієнтами, партнерами та підлеглими, тому в них майже не лишається часу на розвиток команд і тим більше на особисте життя. Постійне перебування в ефірі призводить до емоційного вигорання, яке згодом може перерости в депресію. Тому в багатьох європейських країнах - як на законодавчому рівні, так і в межах організацій - запроваджують право працівників на відключення від пошти, телефону і месенджерів у неробочий час [4]. 
6. Зменшення розбіжностей між різними поколіннями працівників. Роботодавці зазвичай сегментують працівників з точки зору приналежності до певних поколінь для розробки кар'єрних можливостей, програм розвитку та підходів у рекрутингу. Однак, останні дослідження показують, що насправді розбіжності між поколіннями $\epsilon$ меншими, ніж ми досі уявляли, особливо в таких сферах як очікування лояльності до працедавця і гарантії зайнятості, а також очікування щодо кар'єрного зростання. Кар'єра стає динамічнішою, тому історична залежність між віком та можливостями просування кар'єрними сходами послабляється[4]. У цих умовах компаніям треба застосувати підхід на основі аналізу даних, аби краще розуміти унікальні характеристики й потреби працівників та ефективніше використовувати можливості персоналу. Якщо компанії зможуть краще зрозуміти своїх працівників, вони будуть здатні розробляти більш ефективні програми й політики, що сприятимуть підвищенню ефективності працівників.

7. Розвиток персоналу та пристосування до змін. В умовах цієї кризи керівництво компаній отримало змогу перевірити стійкість і здатність персоналу пристосовуватися до нових вимог, адже працівникам довелося швидко брати на себе нові ролі й навіть долучатися до проектів у інших сферах та індустріях. Керівникам необхідно розглянути шляхи заохочення працівників та розширення можливостей для їхнього професійного розвитку й адаптації, зважаючи не лише на їхні навички чи рівень кваліфікації.

8. Стратегія винагороди з фокусом на людину. Сучасні реалії вимагають від компаній перегляду політики оплати праці, адже деякі низькооплачувані професії виявились нагальними й затребуваними в умовах кризи. Дослідження свідчать, що провідні компанії впроваджують різні заходи 3 перегляду оплати праці: деякі організації підвищили мінімальну заробітну працівникам, які виконують важливу роботу, інші скоротили компенсаційні виплати керівникам, намагаючись завдяки цьому зберегти робочі місця [3]. Отже, керівникам компаній доцільно визначитись, на яких принципах вони будуватимуть свою стратегію винагороди. У процесі формування таких принципів не варто обмежуватися лише ринковою вартістю праці. Ці принципи мають брати до уваги людську цінність у формі покликання, справедливості, прозорості, а також можливості кар'єрного зростання та співпраці.

Виходячи 3 вищезазначеного, для побудови ефективної стратегії управління персоналом, менеджменту компаній в умовах пандемії слід зосередитись на наступних важливих завданнях:

опрацювання сценаріїв тимчасового скорочення персоналу та підготовка співробітників до можливості таких змін;

створення багатофункціональних команд менеджерів для вирішення проблем управління персоналом та адаптації персоналу до ризиків, що несе нестабільне середовище на ринку праці в умовах пандемії;

посилення інформаційної комунікації та взаємодії з працівниками, зміцнення організаційної культури та цінностей компанії;

розробка та впровадження гнучкого графіку та можливостей дистанційної роботи; організація надання психологічної та матеріальної підтримки співробітників, створення безпечного робочого середовища та атмосфери добробуту.

Висновки. Таким чином, вищезазначені аспекти $\epsilon$ актуальними трендами сьогодення, які доцільно враховувати при формуванні сучасної стратегії управління персоналом. При цьому, на наш погляд, з боку керівництва компаній потрібні швидкі та суттєві дії, такі як: відхід від вузького сприйняття викликів щодо людського капіталу і усвідомлення масштабності ролі людини, переосмислення звичних підходів до роботи 3 
персоналом, пошук i закріплення нових практик, які б враховували потреби працівників, їхні життєві обставини, стан здоров'я, покликання і можливості. Все це сприятиме досягненню важливої стратегічної мети - успішному поверненню персоналу до роботи в звичайному режимі в майбутньому періоді після закінчення пандемії COVID-19.

\section{СПИСОК ВИКОРИСТАНИХ ДЖЕРЕЛ}

1. Як пандемія COVID-19 змінила ринок праці в Україні. URL: https://www.ukrinform.ua/rubric-society/3104312-ak-pandemia-covid19-zminila-rinok-praciv-ukraini.html.

2. Корнієнко Я. Ринок праці у 2020: попит на гуманітаріїв і пенсіонерів, штатний психолог, Siri та моніторинг працівників. URL: https://www.epravda.com.ua/publications/2020/01/15/655668/.

3. Бойченко О., Тимченко Н. Повернення до роботи в нових умовах. URL: https://www2.deloitte.com/ua/uk/pages/human-capital/articles/hc-trends-covid-19.html.

4. Який він - роботодавець мрії 2020? Топ-9 HR-тренди в епоху пандемії. URL: https://www2.deloitte.com/ua/uk/pages/press-room/press-release/2020/hr-pandemic-

trends.html.

5. Як зменшити вплив пандемії на співробітників: інструкція управлінця. URL: https://www2.deloitte.com/ua/uk/pages/human-capital/articles/impact-of-covid-19.html.

\section{REFERENCES}

1. Yak pandemiia COVID-19 zminyla rynok pratsi v Ukraini [How the COVID-19 pandemic changed the labor market in Ukraine]. URL: https://www.ukrinform.ua/rubricsociety/3104312-ak-pandemia-covid19-zminila-rinok-praci-v-ukraini.html. (in Ukrainian)

2. Korniienko Ya. Rynok pratsi u 2020: popyt na humanitariiv i pensioneriv, shtatnyi psykholoh, Siri ta monitorynh pratsivnykiv [Labor market in 2020: demand for humanities and retirees, staff psychologist, Siri and employee monitoring]. URL: https://www.epravda.com.ua/publications/2020/01/15/655668/. (in Ukrainian)

3. Boichenko O., Tymchenko N. Povernennia do roboty v novykh umovakh [Return to work in new conditions]. URL: https://www2.deloitte.com/ua/uk/pages/human-capital/articles/hctrends-covid-19.html. (in Ukrainian)

4. Yakyi vin - robotodavets mrii 2020? Top-9 HR-trendy v epokhu pandemii [Who is he - the employer of the dream 2020? Top $9 \mathrm{HR}$ trends in the era of the pandemic]. URL: https://www2.deloitte.com/ua/uk/pages/press-room/press-release/2020/hr-pandemic-

trends.html. (in Ukrainian)

5. Yak zmenshyty vplyv pandemii na spivrobitnykiv: instruktsiia upravlintsia [How to reduce the impact of a pandemic on employees: a manager's instruction]. URL: https://www2.deloitte.com/ua/uk/pages/human-capital/articles/impact-of-covid-19.html. （in Ukrainian)

Панченко И.В., кандидат экономических наук, доцент, Донецкий национальный университет имени Васыля Стуса, ORCID: 0000-0001-5010-5810

i.panchenko@donnu.edu.ua

Середа А.В., кандидат экономических наук, доцент, Донецкий национальный университет имени Васыля Стуса, ORCID: 0000-0001-9222-1887

g.sereda@donnu.edu.ua

ТРАНСФОРМАЦИЯ СТРАТЕГИЧЕСКИХ ИМПЕРАТИВОВ УПРАВЛЕНИЯ ПЕРСОНАЛОМ В УСЛОВИЯХ ПАНДЕМИИ COVID-19 
В статье исследованы особенности трансформации стратегических императивов управления персоналом в компаниях в условиях пандемии. Акцентировано внимание на том, что пандемия и связанный с ней экономический кризис требуют от владельцев компаний использования действенньх инструментов преодоления негативных последствий и адаптации к нынешним условиям существования на рынке, а также сохранения главного ресурса компании - персонала. Доказано, что в современных реалиях значительным преимуществом для компаний в конкурентной борьбе за выживание могут стать правильно установленные стратегические императивы управления персоналом, учитываюшие изменения во внутренней и внешней среде организации, на рынке труда, в экономике и обществе в иелом. Определено, что ключевым направлениям, на которые руководству компании целесообразно обращать внимание при формировании HR-стратегии, являются: создание ощущения принадлежности персонала организации; обеспечение эффективного взаимодействия людей и технологий; распространение системы накопления знаний и использования искусственного интеллекта; обеспечение благоприятных условий для решения этических проблем; создание комфортной среды для благосостояния работников; содействие уменьшению разногласий между различными поколениями работников; формирование системь развития персонала и приспособления $к$ изменениям; имплементация стратегии вознаграждения с фокусом на человека. Полученные результаты предлагается использовать для дальнейтего детального и системного изучения влияния пандемии на трансформацию стратегических императивов управления персоналом в контексте глобальных изменений трудовых отношений.

Ключевые слова: управление персоналом, стратегические императивы, трансформация, пандемия, персонал организации, HR-стратегия, организациия труда.

I. Panchenko, PhD in Economics, Associate Professor, Vasyl' Stus Donetsk National University, ORCID: 0000-0001-5010-5810

i.panchenko@donnu.edu.ua

H. Sereda, PhD in Economics, Associate Professor, Vasyl' Stus Donetsk National University, ORCID: 00000001-9222-1887

g.sereda@donnu.edu.ua

\section{TRANSFORMING STRATEGIC IMPERATIVES OF HR-MANAGEMENT IN THE COVID-19 PANDEMIC}

In the article the features of the transformation of strategic imperatives of personnel management in companies in a pandemic is examined. Emphasis is placed on the fact that the pandemic and the associated economic crisis require business owners to use effective tools to overcome the negative consequences and adapt to current market conditions, as well as to preserve the company's main resource - staff. It is proved that in modern realities a significant advantage for companies in the competition for survival can be properly established strategic imperatives of personnel management, taking into account changes in the internal and external environment of the organization, labor market, economy and society as a whole. It is established that the key areas that the company's management should pay attention to when forming an HR strategy are: creating a sense of belonging to the staff of the organization; ensuring effective interaction of people and technologies; dissemination of the system of knowledge accumulation and use of artificial intelligence; providing favorable conditions for solving ethical problems; creating a comfortable environment for the welfare of employees; helping to reduce disparities between different generations of workers; formation of a system of personnel development and adaptation to change; implementation of a reward strategy with a focus on the person. It is proposed to use the obtained results for further detailed and systematic study of the impact of the pandemic on the transformation of strategic imperatives of personnel management in the context of global changes in labor relations.

Keywords: personnel management, strategic imperatives, transformation, pandemic, personnel of the organization, HR-strategy, labor organization. 